HStud 24 (2010)2, 225-244

DOI: 10.1556/HStud.24.2010.2.5

\title{
ALEAS OF HISTORY AND FRONTIERS OF MODERNITY
}

\author{
LÁSZLÓ RAVASZ (1882-1975) AND THE INTERWAR \\ CATHOLIC-PROTESTANT RAPPROCHEMENT IN HUNGARY
}

\author{
PÁL HATOS
}

Balassi Institute, Budapest

Hungary

\begin{abstract}
Liberal academics and enthusiastic lay audiences hailed the public debuts of the Calvinist theologian and acclaimed orator László Ravasz as the leading representative of a new generation of modernist clergymen in the early 1910s. Much to the regret of his liberal critics, in the wake of the collapse of historic Hungary following World War I his message stemmed from a modern cult and culture of defeat and was in no way a continuation of the old school liberals of the belle époque of the Dual Monarchy. In his memoires, which were written during the 1960s, Ravasz described his erstwhile political views as "fetishes," but defended his theological motives. This raises questions concerning a central problem of modern religious experience: how can one map the constantly evolving frontiers between rampant secularization and the no less permanent and certainly insatiable nostalgia for the sacred order of things in modern societies? By redefining what is religious, the currents of Protestant and Catholic thought in interwar Hungary presented in the following article established intellectual contexts on both sides that make not only the historical description of Christian identity but also the very notion of modernity a function of multi-layered readings. At the same time, the Catholic and Protestant rapprochement may be interpreted as a symptom of the decline of religious explanations of the world and history, because they testify to the fact that the dialectics of historical interpretation are no longer defined by the particular approaches of Catholic or Protestant theology or the differences between the two, but rather by the state of competition between universalist utopias and religious world explanations forced into the conservative camp, which necessarily bleaches the emphatic elements of Christian teachings as well.
\end{abstract}

Keywords: László Ravasz, Ottokár Prohászka, Béla Bangha, religion, history, theology, Catholic-Protestant rapprochement, Hungary, modernity

Ever since anticipation of the last days predicted by Christianity ceased to determine European history and political action, religious indifference has been the unifying force on which the integration of the political community has been built. Nonetheless, as the development of modern historiography clearly demonstrates, 
the separation of religion and politics is a much more complex issue than one might customarily assume it to be. As Arnaldo Momigliano once said,

\begin{abstract}
Paradoxically, Christian ideas penetrated into modern historical books only in the eighteenth and nineteenth centuries, when faith in Christianity was at its lowest. [...] When that happened, modern historical methods had already been shaped upon their ancient models. Modern philosophy of history - on a Christian basis - and modern historical methods - on a classical basis - have never quite agreed with each other (Momigliano, 1990, 156).
\end{abstract}

This insoluble dilemma was responsible in the Enlightenment tradition of the secularization thesis that the history of religious questions in a large part has been transformed into an operation of uncovering ideological instrumentalization. Similarly, the semantically pregnant language offered by the Christian tradition has also been metamorphosed into a historical storehouse of symbols to be suppressed or, failing suppression, constantly reinterpreted, that is, secularized. Nevertheless, the existential vertigo felt over choices between alternative actions and articulated in the language of religion has a strong political relevance which is structurally present in modern history as well.

It is generally understood that as a metahistorical concept modernity can be interpreted as discontinuity, the unfolding of the Promethean myths of the revolution, a rich and ever renewing production of the philosophies of progress and emancipation. But from the onset it also displays an equally important other side in the forms of nostalgia and reaction (Starobinski, 1966, 81-103; Boym, 2001, $3-32$ ). Modernity in more than one aspect is the culture of defeat. The bold earthly desires of the prophets of modernity arose less and less from the experiential horizon of the past, while the increasingly radical paradigms of progress, treading on one another, are at the very moment of their realization crushed by the barren experience of unfulfilled expectations and the malaise bred from insatiable desires. Since the mainstream rationalist tale of the secularist thesis suffers from serious deficiencies, an alternative is needed. When speaking of the modern situation of the religious experience, one alternative lies in the historical exploration of a cultivated sense of victimhood, deception and defeat as a basis for overcoming the ontological consequences of the failure of the Promethean enterprise.

In this sense, the issue of the religious revival of the Christian churches in the interwar period has yet to enter the professional literature of mainstream Hungarian intellectual and political history. The role of the denominational factor has long been a problem of Hungarian historiography, though mostly treated as and restricted mainly to the institutional and power conflicts of the different churches. Through an examination of interwar Protestantism's leading figure and dominant theologian Calvinist Bishop László Ravasz, as well as of the stances of prominent 
representatives of political Catholicism (such as Ottokár Prohászka and Béla Bangha) on the denominational issue and Christian union, I will attempt to seek an explanation as to how the existential motivations, above all a deep-seated spiritual condition of insecurity originating in the respective theological and historical situations of their Churches, formed Protestant and Catholic religious-denominational identities in 20th century Hungary.

\section{The Intellectual Legacy of Liberal Protestantism}

Following the Kantian and Schleiermacherian currents of West European Protestant theology, 19th century Hungarian Protestantism was receptive to the "horizontal universalism" (to use Benedict Anderson's phrase) present in the national idea (Anderson, 1991, 7). It was more closed, however, to any radically questioning of the historically evolved hierarchy of the social order. It was liberal and national, rather than liberal and democratic, and it felt a greater kinship with conservative liberalism of the Macaulay type than with freethinking radicalism. In one respect liberal Protestantism kept in sight the moral ideal found in the neo-Kantian philosophy of cultural conservatism, which at the turn of the nineteenth and twentieth centuries assumed a peculiar balancing role that moderated the increasingly radicalized intellectual movements. At the same time, it wished to continue to implement consistently the Hegelian principle of progress. Of course, in the long run this was untenable, especially since behind the fecund discourse and artificial activism of liberal Protestantism lurked two suppressed basic problems - or non-dits, to use French historian Michel de Certeau's expression: the embarrassing radicalism of the question of God and the Protestant resentment of Roman Catholicism's much-envied organizational success (Michel de Certeau, $1975,71)$. The latter remained an insoluble problem and lent to the liberal discourse an unmistakably melancholic tone even in the heydays of the liberal century. Nevertheless, by around 1900 the most important menace became the fact that the chief characteristic of Protestant liberalism, the individualistic basic principle of freedom of conscience, was also espoused by the radical ideologies and militant social democracy. In this respect, Protestantism's ostensibly liberal alliance with patriotic ideals, seen as an aim both conservative and apologetic, was especially burdensome. The debate in Nyugat [West], the leading progressive literary and social review of the 1910s, forcefully illustrated the lost magic of the erstwhile "progressive religion." Members of the new generation of intellectuals represented by Nyugat, such as writers and essayists Dezső Szabó (1879-1945), Endre Ady (1877-1919) and Zsigmond Móricz (1879-1942), all of whom had a Protestant background, saw the religious and patriotic potential of contemporary Protestantism exhausted: "The problem of Hungarian Protestantism [...] is that 
the time is fast approaching when this living organization becomes an exhibit in a museum" (Móricz Zsigmond, 1913, 217). Thus these challenges put this fine tuned regime on the defensive vis-à-vis the new, class-based definition of progress and modernity as articulated by socialism. Thus, by the eve of the First World War the intellectual state of liberal Protestantism had been permanently shaken in Hungary.

\section{Religion as Life and Instinct in the Early Writings of László Ravasz}

A new generation of Hungarian Reformed theologians, first and foremost László Ravasz (1882-1975), came to the forefront of church life after the lost war and the collapse of the Austro-Hungarian Monarchy. Liberal academics and enthusiastic lay audiences both hailed his public debuts not only as a theologian but also as an acclaimed orator. At the start of his career in the first decades of the 20th century Ravasz was considered the leading representative of a new generation of modernist clergymen in the first decades of the 20th century. Also a prolific author and a tireless organizer, Ravasz had an innate talent to transmit his message and gain the acceptance both of his peers and large and varied congregations of Protestant circles. He had a synthetic and approachable personality and never hesitated to use the different means of modern media of his time to make his voice heard by many, far more than his predecessors could ever have imagined. His name is rightly associated with the cultural and intellectual appeal of the revival of Protestant religiosity in interwar Hungary while he was elevated to high church offices and decorated by numerous and distinguished official honors. In 1907, at age 25 he became full professor of his alma mater, the Kolozsvár Academy of Reformed Theology, where he taught until 1921. In that year he was invited to serve as pastor of the leading Calvinist congregation of Budapest and was also elected bishop of the Danubian District of the Hungarian Reformed Church. Between 1921 and 1948 (until his forced resignation by the Communist regime), he was one of Hungary's most influential and powerful clergymen. He became also a member of the Upper House of Parliament in 1927 and later of the Royal Gubernatorial Council of Governor Miklós Horthy (1869-1957).

But László Ravasz was not only an outstanding organizer and a perspicacious church politician, he was an innovative theologian as well. Trained in the school of neo-Kantian historicism, the young Ravasz, also a Freemason, was thought by many observers to be a liberal theologian of the left in the first decade of the 1910s. In his early years he argued for a supra-dogmatic religiosity which overcomes the rigidity and the historical aleas of the religious and denominational orthodoxies. In his inaugural lecture as the holder of the Practical Theology Chair of the Kolozsvár Academy of Reformed Theology in 1907 he declared 
all the dogmas, habits and traditional views that have had a great impact on every kind of advancement lost their magic in our eyes. We know that these are only the temporal necessities of the Christian piety, historically accumulated like the time-worn formations of coral-reefs [in the sea] and becoming life-threatening barren cays (Ravasz, 1907, 52).

In an honorary tribute to his ecclesiastical mentor, the liberal theologian and superintendent of the Transylvanian District of the Hungarian Reformed Church, György Bartók (1845-1907), he asserted that, "the theology that disrespects criticism will sink into scholasticism," and expressed a rationalist credo by repeating the apology of 19th century liberal German theology that "we can make the world believer only by the cost of critique" (Ravasz, 1908, 645-52).

But Ravasz was always more than a mere follower of neo-Kantian rationalism. Although he wanted to be "modern and constructive," his critic also targeted the deistic deviations of the contemporary Calvinist preachings, which bypassed the core-teachings of Christianity and Jesus himself and failed to offer an authentic religious Erlebnis beyond the customary "empty phrases" on conventional topics and nationalistic commonplaces. In order to find alternatives to and transcend the dried-out resources of contemporary Calvinist homiletics, Ravasz enthusiastically embraced a vitalist reassessment of the religious experience inspired by the Dionysian cult of the instinct as put forward by the post-Nietzschean atmosphere of his school years in the first decade of the 20th century:

\footnotetext{
It will be the business of future historians of the coming age to discover the ties between the assaulting anti-Christianism of Nietzsche and the revolutionary transformation of modern theology, ties that provide a bridge across the abyss now stretching between the theological and scientific worldviews, but as for me with thanksgiving I bless the name of the Lord who even in the words of the fools bears witness of Himself... Indeed all should agree that the concept of life cannot be limited to vegetative existence (Ravasz, 1907, 20-1).
}

The young Ravasz reinterpreted Christianity as life, as more life, and as an impulse and an instinct ("vallásösztön," Ravasz, 1918, 7). In 1910, in the first collection of his sermons, a genre he cultivated from his time on with huge success, he affirmed that,

the higher and purer the growing life is the nobler, more spiritual and more valuable the joy is (Ravasz, 1910, 113).

These were not the conventional elements of Calvinist preaching, and Ravasz's fresh new discourse attracted a number of modernist scholars who were overtly discontent with the predominantly historicist Hungarian intellectual tradition. 
The art theorist Lajos Fülep (1885-1970), member of the so-called Sunday Circle [Vasárnapi Kör], an intellectual group including such personalities as Georg Lukács, Karl Mannheim, and Karl Polányi, particularly welcomed Ravasz's growing influence and urged him to cooperate with left-wing-progressist periodicals like the Twentieth Century [Huszadik Század] of the radical sociologist and politician Oszkár Jászi (1875-1957) and World [Világ] of the Marxist theorist Ervin Szabó (Fülep, 1918, 367).

\title{
The Trauma of Defeat: The Making of a Conservative Theology
}

In the crucial years of the First World War, however, Ravasz moved in the opposite direction, and from 1921 on he definitely made his name famous as one of the most important spokespersons of the conservative turn of the interwar period. This turn indeed was not without prior experiences in the earlier career of Ravasz. His most important intellectual encounter was a Schopenhauerian reading of the mal-de-siècle, which he thought to be a legitimate reaction to the advance of the materialism of the industrial revolution and the coming of the age of class society and its socialist challenge (Ravasz, 1907). This par excellence aesthetical approach and Ravasz's appropriation of such prophets of the despair as Schopenhauer and Nietzsche already pointed out the potentiality of an anti-liberal theology. In a short essay written in 1914 he defined life as a "sublime and permanent fight of self-defense" (Ravasz, 1914 2 ,202). This essay was published in the Protestant Review, the editorship of which Ravasz took over in January 1914, quickly making it an important and much read forum of intellectual debate on religion and Protestantism (Szegedy-Maszák, 1995, 57-9). In his first editorial note he characterized the contemporary situation of Hungarian Protestantism as "unaware of itself" (Ravasz, 1914, 1). He rejected the remaining illusion of the liberal protestant alliance and also dismissed the inward looking pietism as escapism, warning that

\begin{abstract}
a new social order is under construction without Protestantism being among the foremen, the modern man has arrived on his long journey from the Renaissance but is not accompanied by Protestantism, so we would be like the bark in the poem of Thomas Moore which moved gloriously on when morning was shining, but the waters were gone by night and the bark was still there, run aground (Ravasz, 1914 ${ }^{1}, 3$ ).
\end{abstract}

As previously mentioned, Ravasz's transformation was accelerated during World War I. He emphasized with increasing clarity that the objective of his much appreciated sermons was, "to show how the old truth can be dressed in modern literary forms" (Ravasz, 1917, Foreword). This also drove him to prefer practice to 
theory. He finished his treatise on the axiology of Károly Böhm in 1913 and published his voluminous Homiletics in 1916. These were his last scholarly syntheses for decades. From 1914 he became more and more involved in the government of the Church and he constantly preached. His lecture tours aimed to give a modern meaning to missionary efforts, especially for the cultured middle classes, and to reconcile institutional Christianity with the revival spiritual movements, domesticating the non-conformist tendencies of the inner mission by integrating them into a new offensive pastoral strategy of the official Church.

Recently, Dutch psychologist and historian Eelco Runia forcefully argued that, "it is the degree of discontinuity rather than the amount of death and destruction that makes an event traumatic" (Runia, 2010, 6). This makes intelligible the fact that Hungary's trauma of the Great War fed mainly from the humiliating defeat and dismemberment of the country after the war and not from the troublesome memory of the trench-fight and the colossal losses Hungary paid in human life and blood. Like many of his contemporaries, Ravasz also wanted to sublimate the historical experience of the national catastrophe that took place between 1918 and 1920, as well as the sense of threat felt in the shadow of the increasing influence of totalitarian ideologies. According to his reminiscences,

The situation developed in such a way that it was necessary to choose between two extreme either-or oppositions. In vain did someone approve of social reform, the inflexibility of ideological necessity drove him into the opposite camp. Everything that attacked the old was good, even if it upset the eternal laws of morality, and nothing that sought to preserve the old was good, even if that old was called the Ten Commandments or the Sermon on the Mount... In this fight it was necessary to defend protective, inoculating factors such as religion, church, morals, nation, history and tradition. They had to be defended in such a way that we preserved the reformist legacy and kept the Roman leaven at bay, while feeling ourselves to be one with it in Christ; to go as far as possible along the path of radical progress, but without supporting the diabolical calamity of godlessness anywhere. Looking back today [1960], when a great many things confront us in a completely different light, it is clear to us that a radical social policy should have been pursued based on a strong evangelical inspiration. We who defended Hungary's historical integrity, who proclaimed the primacy of the spiritual, who espoused the truth of Revelation, who raised our voices in favor of the absolute value of morality, in a world that had slowly begun to unravel and crumble, could not have done anything else than what we did: to try to preserve the good (Ravasz, 1992, 122-3).

This text captures the sense of a combination of threats to religious, national and historical existence. Despite the retrospective documentation (1960), the authen- 
ticity of the intensity of the experience is reinforced by the fact that the author of these memoirs looks back at his years of change critically and acknowledges that in more than one case the ideals under attack were "fetishes." Back in the 1920s the narcissistic frustration and the rhetoric of shame can be amply documented in such declarations as his memorial speech on Count István Tisza, a Protestant magnate and leading figure of the liberal-nationalist politics of the pre-1914 period:

\begin{abstract}
We put down our arms and Rákóczi's nation did not make a single sword-cut to protect the Hungary that she at last proclaimed independent. [...] The nation lost everything like the donkey surprised to be stripped off his stolen tiger fur (Ravasz, 1924, 15).
\end{abstract}

In the dreadful perspective of revolutionary totalitarianism offered by the short-lived Hungarian Commune in the spring of 1919 many erstwhile liberals sought refuge in the idea of a Christian Hungary with strong ethnic and many times overtly expressed anti-Semitic overtones. Christian churches, both Catholic and Protestant, experienced a renewal of their impact on society in the interwar period. They were able to count on the continuous good will of the Horthy regime, which shifted between liberal conservative and marked authoritarian tendencies throughout the whole period. But the spectacular religious upheaval was seen by quite a few observers with strong reservations. For the philosopher and essayist Béla Hamvas (1897-1968) the "Heideggerian condition" of contemporary religiosity bode ill. As he wrote with prescience in the Catholic Review in 1937,

Some words need to be added about this modern religiosity. It has to be admitted that part of the religiosity that has been spread after the past war does not offer much for the man of the intellect. All signs point to our being just after one worldwide man-slaughter and facing a new one: an intermezzo between two mass massacres. We are facing hunger, epidemics, disability, ruined existence, privation and poverty, and it may well be that some years later all repeats itself at an even greater degree. People are threatened and the way they live today - poor living conditions, social problems, economic and moral depression - cannot dismiss this fear. All these circumstances made man conscious of his being a creature, namely that he is living in the state of throwness - Geworfenheit to use Heidegger's word - : his concerns about living, subsistence, the mother country and the family are like thick, heavy, depressing clouds. And religiosity, which is the reason for today's overcrowded churches and the many prayers, often springs from these concerns. Certainly, the majority of the crowd cannot see the divine reality. Which moment is the moment when man can touch and recognize it? Which is the step that leads someone beyond concerns, fear and intimidation into the real gate of religion? This is the moment when one learns about eternity (Hamvas, 1937, 611-12). 
Little wonder that the "pagan temptation" to instrumentalize Christianity has in numerous cases been explored by the prophets of violence. As in most parts of Europe, these voices echoing the experience of defeat and broken confidence were amplified by the receptive mood of their many followers. In this respect the widely shared self-perception of a nation defending itself against its internal and external foes, the craving for continuous political preeminence, and first and foremost the underlying "great fear" of being out-distanced and relegated to the position of an inferior sect were at least as prevalent as genuine religious factors in shaping the confessional policy and behavior of the Christian Churches in interwar Hungary.

What distinguishes Ravasz from this pattern is that in his case an enthusiastic embrace of new forms of propagating and reinforcing religious observance was accompanied by a sincere return to the reformatory teachings of Predestination. The anxious awareness of an all-encompassing menace pushed him to the reformulation of the primordiality of the religious roots of Protestantism in the Calvinist doctrine of election and predestination. The obligation to stand one's ground firmly in the face of the threat defines Ravasz's preaching between the two world wars. The sense of threat finds an active resolution in the belief in Predestination. Ever since he read Calvin his exegesis focused on the idea of a sovereign God:

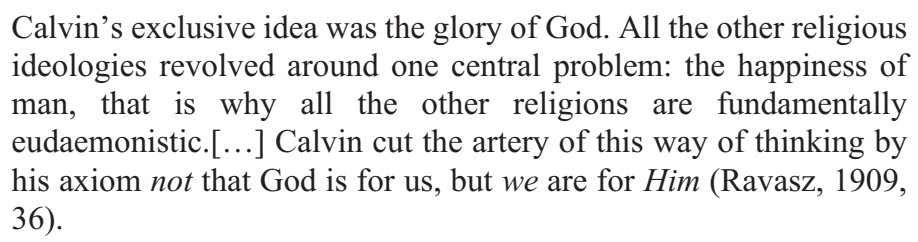

This standpoint is reminiscent of the functional explanation of the doctrine of predestination by Heiko A. Oberman (Oberman, 2003, 148-9). Oberman recognizes the attractiveness of this grim vision of the world in the existential situation of the defeated. Predestination is the core teaching of the Reformation of the Refugees. The dynamics of an imminent destruction found a tremendous assurance in the absoluteness of divine sovereignty:

God has redeemed us in a way similar to how the grains are included in a granite block, we cannot be separated from Him as you cannot remove the grains even after smashing the granite block (Ravasz, 1922, 101).

As might be expected, this doctrine concedes almost nothing to human endeavors and consequently deprives the concept of progress of whatever positive value it might hold: "in God there is no temporal difference or difference whatsoever between intention and result." On the other hand, he fosters a highly dichotomic an- 
thropology of history and social interactions: "God has created our world so that the small number of the chosen few necessarily points to the great number of the rejected" (Ravasz, 1922, 100). One of the main characteristics of this existential-predestinatory attitude is the marked relativization of man's freedom of action, as a result of which the thought-pattern of progress necessarily becomes devalued.

\section{Towards a New Appraisal of Catholicism}

The existential situation that affected the theological stance of Ravasz was also reflected in a new kind of appraisal of contemporary Catholicism. Ravasz's interwar image of the Reformation anticipates the conclusion reached by most of the mid-century church historiography that the centuries-long preparation for religious renewal led not only to the birth of Protestantism but to the "Tridentine renewal" of Catholicism as well:

The Cluniac reform of the medieval church should be called a reformation, just like the Council of Trent, which carried out the greatest and most characteristic reformation from a Catholic viewpoint (Ravasz, 1935, 503).

The significance of the Reformation thus becomes integrated into an approach justifying the historical pluralism of the modern era on religious grounds:

Here two historical forces, two types of Christian world view and life practice confront each other. This is not just a theoretical or theological difference, but a development of cultural history as well, and as such, it is a basic factor of the human spirit itself (Ravasz, 1934, 497).

In another lecture Ravasz evaluates the significance of the Protestant-Catholic divide in contrast to the tradition of the Enlightenment:

\footnotetext{
Since the creation of the world every spiritual question has been transformed into a political and economic question... we cannot imagine a greater betrayal, a graver sin against the Holy Spirit than if someone were to keep silent about a spiritual truth which he feels to be God's holiest cause simply because espousing and proclaiming it would have unpleasant consequences on account of rotten human nature. This would excise the history-shaping power of the prophetical from the living organism of humanity (Ravasz, 1936, 511).
}

The highlighting of the prophetical and the acceptance of religious pluralism expresses not merely the experience of crisis but also "today's apocalyptic times," when Christianity "is threatened in its entirety" by Communism and Nazism: 
Christianity has hidden common bases which are greater, more essential and more important than the torn or divided superstructure (Ravasz, 1937, 161-5).

It is of no small importance that, through the interpretation of predestination, the most particularly Calvinist idea of reformatory identity, Ravasz found the current duties of Protestant conduct in an image of society and a strategy of action kindred to those of contemporary Catholicism. This may appear paradoxical at first glance, because the rapprochement represented a problem even more difficult for its Catholic proponents than for the Protestant side. The Catholic-Protestant relation was far from being an unambiguous issue. But behind the spectacular instances of conflicts and the sometimes comical rivalry over preeminence a new commencement was at work.

\section{"And after all, What Do Our Faiths Have in Common?" The Catholic Motivations of the Rapprochement}

The trauma experienced by the Roman Catholic Church in 19th century Europe was first and foremost the seemingly triumphant march of the triangular synthesis of liberalism, nationalism and progress. This story is known from various angles, and narratives of decadence and reactionary opposition prevail in most of the scholarly literature. Much less has been written about how Catholicism overcame the modernist crisis with a successful adaptation of the very same semantic instruments that liberalism and nationalism established in the political language. By setting up frontiers and crystallizing distinctively modern confessional attitudes (a Catholic mentalité) in the wake of the 19th century Kulturkampfs, the Roman Catholic Church found ways to take possession of some of the very inventions of modern times, such as the concept of the nation and the democratic politics of emancipation (Blaschke, 2000, 35-75). The lasting impact of the Hungarian "Catholic Renaissance" (1894-1948) also comes from the reappraisal of "universal brotherhood" (Benedict Anderson) implicit in all nationalism and the appropriation of such fundamentally modern ideas as universal suffrage and the defense of religious liberty, both in the name of the democratic majority (i.e. the Catholics who made up statistically more than two-thirds of Hungary's population after 1920). From the Christian-socialism of the charismatic bishop and controversial theologian Ottokár Prohászka (1858-1927), initiator of the "Catholic Renaissance," to the popular Marian nationalism of Joseph Cardinal Mindszenty (1892-1975), many inspired leading Catholic churchmen appealed successfully to the synthesis of Catholicism and Hungarian national identity by exploiting the

various instruments and media of modern mass democracy and the politics of the 
"majority." And in the case of Cardinal Mindszenty, in the dichotomy of the Cold War his unswerving anticommunism was seen through his trials by many, especially in the United States, as the authentic testimony of the idea of religious liberty (Mojzes, 1992, 241; O’Connor, 37-66).

This historical metamorphosis can also be tracked by exploring the sinuous intellectual paths of some of the most significant protagonists of the "Catholic Renaissance." The difficulty of the matter is well characterized by the attitude of Ottokár Prohászka (1858-1927), Bishop of Székesfehérvár, towards the Protestant churches. By dint of his intellectual abilities and influence, Prohászka was by far the preeminent theologian among Catholic clerical leaders and initiators of the "Catholic Renaissance." In contrast to the denominational conflicts of the first decades of the twentieth century and the interwar period, Prohászka's biographers refer to the universality of the bishop's thinking, which shielded him from denominational bias. In connection with this, they often cite Prohászka's metaphor of a "rainbow-bridge" as well: "I would like a rainbow-bridge of love to stretch between [Catholic] Pannonhalma and [Calvinist] Debrecen, on which the angels of understanding would tread, and this bridge would be a new Hungarian meridian" (Gergely, 1994, 126). However, Prohászka, who died in 1927, made statements of another character as well. In one of his diary entries for 1922 he writes as follows:

\footnotetext{
It is completely clear to me that in our country one should not think of the struggling sides in terms of Catholic or Protestant, but rather as world historical, and from a theoretical standpoint only thusly: Catholicism or socialism, because revolution, the ancient schism, was in fact an attack against Catholicism, against Christianity. One must not lose sight of this; this does not mean that Protestants are not Christians individually, but the Christian principle is not Protestantism, and indeed, Protestantism denies that. The contrast between Catholic and Protestant is practically anachronistic, a somewhat delayed and artificial and insincere distinction. He who makes it honestly, I mean in good faith, has not reached back to the actual principle: the nature of revolution. I, too, usually proclaim the cooperation between Catholic and Protestant, in as much as ... by this I consider one or two positions as defensible. But not for one moment do I rely on this cooperation. And after all, what do our faiths have in common? [emphasis in the original] (Prohászka, 1997, 185).
}

What is important in the citation is not primarily the statement relativizing his calls for denominational reconciliation, but rather that the mistrust of Protestantism expressed in raw form in his diary stems from the historicization that compares Protestantism's founding event, the Reformation, to the revolutionary principle, socialism. According to the modern history of the concept of revolution, 
revolution is a political slogan that recreates itself incessantly in various positive and negative definitions, but one that also carries within itself the original meaning of the word, the concept of "eternal return," taken from nature (Koselleck, 1985). In this semantic framework Prohászka's historicization links Protestantism and socialism with the "ancient schism," the origin myth, because in this way he can interpret both as a revolt against the divine order, according to the dialectic of the struggle between the true and the false, between good and evil. This exposition reveals the homogenous time of waiting for salvation and the end of days. Like any apocalyptic reading, it does not establish a developmental or qualitative ranking among historical movements, but only their chronological sequence, and it classifies events and processes simply according to whether they build the "city of God" or attack it.

However, the citation also reveals that the above explanatory principle could not have completely satisfied Prohászka, who dealt with the problem of temporality in depth throughout his career and was also familiar with the Bergsonian philosophy of "creative evolution." Behind the statement may lurk the worrisome realization that the dialectic of history is increasingly pushing the theological debate between Catholicism and Protestantism into the background, because the asymmetrical relationship between the revolutionary and utopian mode of thought emerging time and again from the traditions of the Enlightenment and the religions forced onto the defensive questions the very right of religion itself to exist. In another diary entry, he reveals his doubts about whether the professed and represented redemptive truth can be carried to victory in the pluralist maelstrom of truth-demands:

It is extraordinarily difficult for the church to find its place and its way, and namely to reform - as they say - its position vis-à-vis human freedoms in a timely and correct manner. Even now the church holds the view that it should restrict the freedom of evil by force as well, or to break it if this is possible. This is proper if we believe that truth is the exclusive domain of the church; but today's era does not accept this, and thus it arrives at a disadvantaged position vis-à-vis modern culture. But in any case the spirit of the times has changed, in as much as it is considered impermissible to interfere in the moral world by force. And somehow this is true. But this feeling once again may have become general when it became clear with the passage of time that one cannot cope with violence. Now Constantines the Great are of no use to the church, nor are Charlemagnes; and Saint Stephens [here the author is referring to the Hungarian king Stephen I (972-1038), founder of the medieval Hungarian state] only to the extent that they promote morality, and not with the bluster of legalities. I know that in this way, too, we reach a dead-end, but this is perhaps the lesser evil. I am dumbfounded (Prohászka, 1997, 87-8). 
The difficulty of accepting religious freedom as the "lesser of two evils" emerges unmistakably from the lines penned by Prohászka immediately following the collapse of the communist dictatorship of 1919. It is common knowledge that the Catholic Church accepted the principle of religious freedom only with great difficulty, in the wake of the Second Vatican Council. This difficulty arises from the understandable fear that the consistent representation of genuine tolerance may not only relativize our own most sacred convictions, but in the end may even eliminate the objective existence of truth from thought. The price that had to be paid for religious neutrality and for tolerance, as well as for the emancipatory hopes born of the Enlightenment and spilling into revolutionary violence, established the permanent crisis of the European intellect and the culture of crisis in the Western history of ideas of the past two hundred years. At the same time Prohászka was also forced to recognize - and the disparaging reference to the founding father King Stephen, the "Hungarian Catholic" saint par excellence, also expresses this - that religious hopes were suited only to a limited extent to function as the direct source for the formation of political or national will, because their past validity in this regard represented a dubious and always ephemeral solution. In that respect another leading conservative thinker of the period, the historian and devoutly Catholic Gyula Szekfü (1883-1955) found the roots of the aggressive and omnipresent modern-day nationalisms in the chaotic conflicts of the primitive tribal societies. He could not assign the national idea anything more than a mimetic calling: "to try to invoke the unequalled classical ideal of the Greco-roman civilization in the heart of all nations" (Szekfü, 1934, 441; Szekfü, 1936, 149).

\section{"Christians of the World, Unite!"}

An article about the possibilities of a Christian union written by the famous (and infamous) standard-bearer of political Catholicism, the Jesuit Béla Bangha (1880-1940), and appearing in 1937 with the astonishing paraphrase of the slogan of the Communist Manifesto, "Christians of the World, Unite!" was influenced to a great degree by these realizations. The study, which in any case surprised his contemporaries as well, was a radical departure from his earlier polemical and militant stance. This was first of all because of the fact that it expressed the uncomfortable realization of the discontinuity of history, as well as acknowledgement that the desire for the unification of Christians and the possible realization of Christian unity must come about not simply as the restoration of some natural order of things, but as a response to a new historical situation undeniably bearing its own uniqueness: 
The age of denominational wars and polemics has long passed; in their place, however, the far-reaching secularization of life and culture is striking, the cause of which is partially the divide among Christians. In families, companies, associations or community houses of mixed faith, out of sheer tact alone no one really raises questions of religion anymore; the result of which later is that the most beautiful, noblest ideals, those that most profoundly interest human life and are called upon to elevate it, are increasingly excluded from public thought and public attention (Bangha, 1937, 15).

This statement does not dispense with a profound sense of nostalgia either, which is fueled by melancholy stemming from the radical change in the historical situation:

Only by rising not to historic but almost metaphysical heights can we truly comprehend the great need for a revision of the denominational situation. What a blissful and, we might even say, blissfully simple age it was when everyone still stood on the basis of Christian ideology, so much so that the debate was about whether Christ had decreed seven sacraments, or only two, or three! So much has today's skepticism chewed away and undermined the flooring and soil of our life of faith that today we must now ponder whether we can save for the masses of the coming centuries faith in the personal God himself and the basic tenets of Christianity (Bangha, 1942, 494).

The final phrase in the above passage is in no way a sociological diagnosis, since like Protestant observers, Bangha himself noted the postwar religious upswing, which was not limited to Catholicism. This religious dynamism uniting denominations did not invalidate, but rather confirmed the bitter prognosis, which Bangha applied primarily to religious communities, and which takes as its point of departure the determination that, parallel to the inevitable weakening of the binding force of traditions and customs, religious communities in the future

will undergo enormous crises. Anti-church agitation, anti-religious movements, doubt and indifference, the materialization and sensualization of life, the advancing self-consciousness and individualization of the masses will likely lead to the practical de-Christianization of broad strata, eventually leading to the loss among religious communities of a great share of their members (Bangha, 1942, 411-12).

As can be seen, at the end of the 1930s and start of the 1940s the chief motivating force of Catholic-Protestant rapprochement, emerging on the initiative of Bangha, was precisely Christianity's sense of being "threatened in its entirety," as another Catholic participant in the debate, the Benedictine monk and abbot of 
Pannonhalma Krizosztom Kelemen, put it a few years later. Kelemen, who nurtured warm relations with Protestant leaders like László Ravasz, articulated this idea in apocalyptic images in 1942, in the very middle of the war:

This meeting will have practical significance only if it is able to prevent mutual collapse... Today the Lord once again speaks to us amidst thunder and lightning. This raises the question: shall we continue to wait for more dangerous earthquakes and more terrible storms to destroy our planet, like those which have attacked our blood-soaked land, afflicted by discord, pettiness, selfishness, envy and hatred, and for frighteningly organized forces to be raised to destroy the country of God, to exterminate his followers, so that they might chase God himself from his throne and permanently expunge once and for all the notion of God from the consciousness of the people? (Kelemen, 1942, 116)

In the end, the troubling international situation, the pressure of the National Socialist and Bolshevik menace, and progressing secularization tore asunder the harmonious relationship between religion and culture as contained in the rational conceptual systems of thought, neo-Thomism on the Catholic side and neo-Kantianism on the Protestant side. Imre Révész (1889-1967), the leading Protestant historian of the period and an erstwhile disciple and close ally of László Ravasz, arrived at the conclusion that religious pluralism is only vital if it does not come into contradiction with the calling of the prophets of Christianity. At the same time, this prophetic calling again and again caused the tension between culture and history, as well as eschatological message of Christianity, to appear:

The Scriptures teach us that human history has no imminent final goal at all, and that the ideals of culture are not absolute values (Révész, 1941, 199).

The Catholic Bangha likewise could only maintain his earlier conviction concerning the stubborn presence of religious concerns if he placed them in an eschatological interpretation of the theology of history that superseded the old dichotomy of the Kulturkampf. By doing so Bangha, under the influence of Gyula Szekfü and incidentally representing views similar to those of his Protestant counterparts László Ravasz and Imre Révész, rejected critically the view that instrumentalized Christianity in the service of the national idea:

The Lord God as a national staffage, religious truths as separate Romanian, Turkish or Russian revelations, the gospel as a Hungarian or Armenian or Bulgarian national specialty - these are bizarre conceptual formations (Bangha, 1942, 235). 
In his search for the meaning of centuries-long religious wars in his later writings, Bangha no longer saw in the Reformation the illegal methods of the revolutionary path (which he, too, had condemned previously) and the historical catastrophe of Christianity, but rather the promotion of a Christian existence and mode of action of a new quality:

Cruelty, faithfulness and impatience melted together here to form a peculiar concoction, and perhaps the Lord God permitted this horrible fraternal extermination in the name of faith so that through it the Church might be cleansed and educated, and learn that there is no room for hatred in the defense of a religious ideal (Bangha, 1942, 497).

His predecessor and in part inspiration, Prohászka, when he came to this realization, had written, "I am dumbfounded!" However, in his final studies, Bangha, who on his deathbed in 1940 treaded the interpretational borderline of dogma and also espoused a cautious revision of the image of the church articulated by the Council of Trent, examined the Catholic possibilities for distinguishing between the notions of the visible and invisible church:

But however much we Catholics recognize the correctness and necessity of the position of the Council of Trent, that is, however much we affirm that Christ our Lord founded not only an invisible but a visible church as well, and wanted not only an abstract unity among his followers but an organizational unity as well, nevertheless we still cannot deny, and the Council of Trent did not wish to deny either, that outside of the community of the church organization we should recognize the community of faith as well (Bangha, 1942, 465).

In fact, in his late, posthumously published writings Bangha, quoting the writings of the French Dominican monk Yves Congar, the spiritual progenitor of the Second Vatican Council, wrote of the partial fulfillment of the universality of Catholicization taking place within the Catholic Church, and in doing so even arrived at the concept of a votum baptismi implicitum, which later served as the basis for Karl Rahner's all-inclusive conception of Christianity:

We can comprehend the ecumenical idea in another way too: based on the complete, even if only desired, unity and life of faith that can be found in every kind of Christian denomination, we can regard as one all those who until now failed to carry out their solidification into the complete and organic unity only because they had not yet recognized the proper way to do so and God's will regarding this. They may rightly be regarded, to a certain degree unconsciously, as children of the Catholic Church, mainly if, by virtue of a life of faith, they 
too are undoubtedly living members of that mysterious body that is the Church (Bangha, 1942, 460).

Outside of their specific content, all of these statements have significance from a historical perspective, primarily on account of their chronology, because the temporal dimension of the statements quoted testifies to the profundity of existential involvement, especially considering that while a large part of their authors' lifework, when viewed from the present day, can be classified as an extremely problematic, and in many respects irrelevant, mode of thought, in one of their conclusions the writings quoted above anticipate the attitude and image of the church held by a theological-intellectual movement still emergent in many respects today, the Second Vatican Council. The late and radical turnabout in the career of the Jesuit Bangha - from the exclusivity of the political Catholicism he himself militantly represented to the existential experience of an ecumenicalism that moved beyond denominational and national conflicts - is also interesting with regard to the connections between the history of ideas and biography. As in the case of Ravasz, his turnabout was undoubtedly a conservative one, attempting to reconcile conflicting identities defined on a dogmatic basis rather than - in contrast to the intellectual traditions of the Enlightenment - relativize them. By redefining what is religious, and thus partially re-articulating the religious attitude, the currents of Protestant and Catholic thought in interwar Hungary presented above established on both the Protestant and Catholic sides intellectual contexts which make not only the historical description of Christian identity but also the very notion of modernity a function of multi-layered readings that are dynamic and pluralistic on the individual level as well.

But at the same time the rapprochement of Catholic and Protestant interpretations of history may be interpreted as a symptom of the decline of religious explanations of the world and history. They testify to the fact that the dialectics of historical interpretation are no longer defined by the particular approaches of Catholic or Protestant theology or the differences between them, but rather by the state of competition between universalist utopias and religious world explanations forced into the conservative camp, which necessarily bleaches the emphatic elements of Christian teachings as well.

\section{Acknowledgements}

The author would like to express his sincerest thanks to the Bolyai Fellowship Program of the Hungarian Academy of Sciences for supporting research on which this article was based. 


\section{Works cited}

Anderson, Benedict (1990) Imagined Communities: Reflections on the Origin and Spread of Nationalism (London: Verso).

Bangha, Béla (1937) 'Keresztény unió?’ (A Christian union?), Magyar Szemle, 2, 15.

Bangha, Béla (1942) 'Miben engedhet a protestantizmus?' (On what can Protestantism yield?), in Bertalan Bíró (ed.) Keresztény unió. Bangha Béla S. J. összegyüjtött munkái XXIV [Christian union. The collected works of Béla Bangha, S. J.].

Bangha, Béla (1942) 'Betessékelés?' (Driving them in?), in Bertalan Bíró (ed.) Keresztény unió. Bangha Béla S. J. összegyüjtött munkái XXIV (Christian union. The collected works of Béla Bangha, S. J.), 465.

Blaschke, Olaf (2000) 'Das 19. Jahrhundert: ein Zweites Konfessionelles Zeitalter?' Geschichte und Gesellschaft, Vol. 26, 38-75.

Boym, Svetlana (2001) The Future of Nostalgia (New York: Basic Books).

De Certeau, Michel (1975) L'écriture de l'histoire (Paris: Gallimard).

Fülep Lajos (1918) Dóra F. Csanak (ed.) (1990) Fülep Lajos levelezése (The Correspondance of Lajos Fülep) (Budapest: Müvészettörténeti Kutató Csoport).

Gergely, Jenő (1994) Prohászka Ottokár. „A napbaöltözött ember” (Ottokár Prohászka. “The man clad in the sun") (Budapest: Gondolat).

Hamvas, Béla (1937) ‘Az örökkévalóság', (The Eternity) Katolikus Szemle, 611-12.

Kelemen, Krizosztom (1942) 'A magyarság lelki egysége felé', in József Barcza (ed.) (1991) Szivárványhíd Pannonhalma és Debrecen között (Rainbow-bridge between Pannonhalma and Debrecen) (Debrecen: Tiszántúli Református Egyházkerület) 115-20.

Koselleck, Reinhart (1985) 'Historical Criteria of the Modern Concept of Revolution', in R. Kosellck (ed.) Futures Past: On the Semantics of Historical Time (Cambridge: MIT Press).

Mojzes, Paul (1992) Religious Liberty in Eastern Europe and the USSR: Before and After the Great Transformation (New York: Columbia University Press).

Momigliano, Arnaldo (1990) The Classical Foundations of Modern Historiography (Los Angeles: University of California Press).

Móricz, Zsigmond (1913) 'A magyar protestantizmus problémája' (The Problem of Hungarian Protestantism), Nyugat, 217.

Oberman, Heiko A. (2003) The Two Reformations. The Journey from the Last Days to the New World (New Haven and London: Yale University Press).

O’Connor, David L. (2006) 'The Cardinal Mindszenty Foundation: American Catholic Anti-Communism and its Limits', American Communist History, Vol. 5, No. 1, 37-66.

Prohászka, Ottokár (1997) Naplójegyzetek III. (Diary entries III) (Szeged and Székesfehérvár: Agapé).

Ravasz, László (1907¹) Schopenhauer aestheticája (The Aesthetics of Schopenhauer) (Kolozsvár: Gombors Ferenc Könyvnyomdája).

Ravasz, László $\left(1907^{2}\right.$ ) Emléklapok Ravasz László tanári székfoglaló beszédéböl (Memorial Pages from the Inaugural Lecture of Professzor László Ravasz) (Kolozsvár: Ellenzék).

Ravasz, László $\left(1907^{3}\right.$ ) Bevezetés a gyakorlati theologiába (An Introduction to Practical Theology) (Kolozsvár: Ellenzék).

Ravasz, László (1908) ‘Dr. Bartók György, mint theológus’ (Dr. György Bartók as theologian), Protestáns Szemle, 645-58.

Ravasz, László (1909) 'Kálvin és a kálvinizmus' (Calvin and the Calvinism), in Az erdélyi református egyházkerület theologiai fakultásának értesitöje az 1909-1910-es tanévröl, 36.

Ravasz, László (1910) Ez ama Jézus (This Is Jesus) (Kolozsvár: Stein).

Ravasz, László (1914¹) 'Beköszöntő' (Welcome adress), Protestáns Szemle, 1. 
Ravasz, László (1914²) ‘A diadalmas élet’ (The Triumphant Life), Protestáns Szemle, 202.

Ravasz, László (1917) Látások könyve (The Book of Visions) (Kolozsvár: Út).

Ravasz, László (1918) Kicsoda az ember? (Who is the man?) (Budapest, B.R.K.I.E.).

Ravasz, László (1922) 'Az eleve elrendelés' (The Predestination), in László Ravasz (ed.) Orgonazúgás (Budapest: Studium).

Ravasz, László (1924) 'Tisza István és a magyar tragédia' (István Tisza and the Hungarian Tragedy), in Két beszéd (Budapest: Stúdium).

Ravasz, László (1934) 'A protestantizmus lényege és sorsa' (The Essence and Fate of Protestantism), in László Ravasz (ed.) (1938) Legyen világosság (Let there be light) (Budapest: Franklin).

Ravasz, László (1935) 'Október 31', in László Ravasz (ed.) (1938) Legyen világosság (Let there be light) (Budapest: Franklin).

Ravasz, László (1936) 'A reformáció mérlege’ (The balance of the Reformation), in László Ravasz (ed.) (1938) Legyen világosság (Let there be light) (Budapest: Franklin).

Ravasz, László (1937) ‘Egység vagy barátság? Válasz Bangha Béla cikkére’ (Unity or friendship? A reply to Béla Bangha's article), Protestáns Szemle, No. 4, 161-6.

Ravasz, László (1992) Emlékezések (Mémoirs) (Budapest: A Református Egyház Zsinat Irodájának Sajtóosztálya).

Révész, Imre (1941) 'Református történetszemlélet' (Reformed History), in Béla Vasady (ed.) És lön világosság. Ravasz László Emlékkönyv (And there was Light. Festschrift in Honor of László Ravasz) (Budapest: Franklin), 193-207.

Ruina, Eelco (2010) 'Into Cleanness Leaping: The Vertiginous Urge to Commit History', History \& Theory, 49, 1-20.

Starobinski, Jean (1966) 'The Idea of Nostalgia', Diogenes, 54, 81-103.

Szegedy-Maszák, Mihály (1995). 'The Protestant Review: Its Past and Present', Hungarian Studies, Vol. 10, No. 1, 55-63.

Szekfü, Gyula (1931) 'Politikai történetírás' (Political history), in Bálint Hóman (ed.) A magyar történetírás új útjai (Budapest: Magyar Szemle Társaság), 395-444.

Szekfü, Gyula (1936) Magyar történet V (Hungarian History, vol. 5) (Budapest: Királyi Magyar Egyetemi Nyomda). 